\title{
THE IMPACT OF E-HRM ON EFFICIENCY IN THE PUBLIC INSTITUTION - CASE STUDY OF LOCAL GOVERNMENT
}

\author{
Adrian Pyszka*
}

\begin{abstract}
Background. Managing a public institution is a complex task with significant effects inside and outside the organisation. Research in the area of managing a public institution shows that it provides new challenges especially in the human resource management (HRM) and the use of IT technology, in particular that today's public institutions are more akin to corporations searching for a higher level of efficiency.

Research aims. The purpose of this article is to identify how IT solutions influence HRM efficiency through effective e-HRM applications, and to explore their role in changing HRM in a public institution. The effects are considered through the theoretical lens of new public management ideas and the efficiency aspects.

Methodology. A review of literature in the field of public management and the use of IT in the HRM was conducted in order to determine what has to be used and how in order to raise its efficiency. The results of literature search were enriched with a case study of an effective government unit and interpreted with reference to literature guidelines. An explorative case study in a public institution was conducted.

Key findings. Using IT in HRM provides more transparency and dynamic relations in HRM, supports improvements by transferring best practices from software vendors, and allows to delegate routine HR activities to line managers and employees. Technology has led to changes in talent management processes. The findings illustrate how staff responsible for HRM reinterpret their roles moving from personnel administration to strategic HRM and business partnership. The study allowed preparing a working model to better understand how to enhance efficiency of e-HRM and performance of the public organisation using IT solutions.
\end{abstract}

Keywords: e-HRM, public management, efficiency, model, case study.

\footnotetext{
* University of Economics in Katowice. E-mail: adrian.pyszka@ue.katowice.pl
} 


\section{INTRODUCTION}

Modern governments have changed their character completely. From institutions perceived as bureaucratic and slow they have become pioneers in the implementation and consistent development of information technology in management, especially human resources management. One such example is the Municipal Office in Zabrze that received the title of the Leader of the Local Government Management 2014 - government as an employer. The prize was awarded for the project "Personnel policy of the Municipal Office in Zabrze based on combining the needs of the employer and employee expectations". This office is an example of introducing many interesting solutions aimed at improving HRM procedures, as well as more efficient managing of the entire teams.

Nowadays, changes emphasise the direction of taking the initiative by public entities and more informed and competent management of the affairs of cities and citizens, also in terms of their activation, as conscious citizens. As mentioned in the SRK document, an extremely important factor in the development of the country is a functioning professional management system in the public sector, where its quality determines the ability of the state to respond to the challenges of the modern world. Such efficiency can ensure the right people that create this system, endowed with adequate management and IT, among others, by: introducing the executive management model (also strengthen the role of leaders and leadership), an assessment of the effectiveness of offices and officers (inspection results rather than procedures), the use of dialogue to communicate with citizens and increase their participation, personnel stabilisation of human resources and increase their competence and motivation, the introduction of ethical standards, risk management and increasing transparency of operation (Strategia Rozwoju Kraju 2020, 2012, pp. 40-44).

In this situation, proper HRM practices in public institutions, supported by appropriate IT solutions enabling improvement in HRM operational efficiency gains and a more strategic role of the HR professionals become a challenge. There is also a lack of publications showing the effects of the implementation of technology in HRM. With reference to the above-mentioned challenges and to bring something important to the discussion, the author decided to combine the 
theoretical assumptions arising from the principles of the new public management ideas. This context presents new managerial challenges where the criticized NPM is focused too much on governance issues that are geared towards principles close to private enterprise management and overly costly, forgetting the challenges of citizens-driven management (Podgórniak-Krzykacz, 2016) and digitalisation waves leading to a digital society (Dunleavy \& Margetts, 2010).

According to the above assumptions the author asks three research questions:

RQ1. What are the stated goals for a public organisation that implement e-HRM?

RQ2. What are the expectations and outcomes by a public organisation as a result of e-HRM implementation?

RQ3. What is the role and influence of IT suppliers on a public organisation that implement e-HRM solutions?

\section{TRENDS IN THE MANAGEMENT OF THE PUBLIC INSTITUTION AND THEIR CONSEQUENCES FOR E-HRM AND ORGANISATIONAL EFFICIENCY}

\section{Trends in public management - from administration to cooperation}

Today's public organisations are focused on continuous improvement of its operations, which means the need to monitor their goals and to take corrective actions. As noted by Frackiewicz-Wronka (2009, p. 41) it means to base their decisions on the results obtained in the measurement process which will enable the assessment of the effects of decisions and thus the degree of fulfilment of stakeholder expectations of public organisations. This trend is known as New Public Management (NPM) that introduces reforms and innovations to enable reorientation in the ways of performing by the public institutions in order to introduce cost-effective and efficient behaviours (Frackiewicz-Wronka, 2009, p. 42). In such a situation, NPM changes the existing paradigm of functioning of public institutions, where the rules of a routinised regime change in the direction of innovation, dynamism, entrepreneurship, and the development of flexible options. 
One of the external factors connected with the development of NPM is Internet technology, that enables electronic communications and IT systems to support business processes (Frąckiewicz-Wronka, 2009, pp. 43-44). As suggested Dunleavy et al. (2006) it could be effective especially in some developing countries where there is an influential additional pathway for organisational change, the impact of largescale contractor involvement in delivering IT-related administration processes on the organisational arrangements and cultures of the agencies they supply.

Currently many authors (i.e. Dunleavy \& Margetts 2010; Greve 2010, 2015) criticised NPM most often perceived as a set of particular management approaches and techniques which are mainly borrowed from the private sector and applied to the public sector. Criticism of the NPM approach is based on its weaknesses as overly focused on results, contracting out, and adopting private sector styles of management practice. According to Greve (2015) new ideas of public management are different from NPM because they avoid pressure on private value creation, using market actors and market-based governance which was common for NPM. Authors such as Dunleavy et al. (2006) and Greve (2015) suggested that new ideas of the public management concentrate better on public value creation i.e. PVM (Public Value Management), DEG (Digital-Era Governance) or CG (Collaborative Governance, also known to some as the New Public Governance - NPG). PVM uses performance orientation of managers in public organisations. In this case it needs digital support and collaborative performance networks. DEG underlines the government's active role in integrating digital solutions which can make new opportunities for data utilisation and public value creation because of input from network actors and their digital solutions. Collaborative governance is focused on shared solutions and linking public organisations, companies, and NGOs. In CG public value creation is also important and it uses digital structures to support collaborative actions.

Alternatively to NPM, conceptions on public management concentrate on trust, transparency, and collaboration. According to Dunleavy et al. (2006) digitalisation (DEG) or e-government are something more than just support for NPM or institutionalisation of IT-technologies. They proposed to use DEG to replace NPM (post-NPM regime) and tendency to disaggregation, competition and incentivisation by using three elements: reintegration, needs based holism, and digitisation processes. 
Dunleavy et al. (2006) mentioned that now there is a digitisation 2.0 process which is more sensitive to the social media including three key issues of digitisation 2.0 i.e.: transparency, social media, and shared services. Transparency, accessibility and responsiveness are key elements to build "open government" which means shifting from "closed files" government on the Weberian pattern to allowing citizens to look at their own medical files and monitor their own treatment or to actively manage their own tax account to greater self-administration (Dunleavy et al., 2006). In this case transparency assumes that the government's actions, and the individuals responsible for those actions, will be exposed to public scrutiny and challenge (OECD, 2005, p. 29). The social media fill the gap and alter the relationship inside government, between politicians and public managers, and with the citizens. According to Greve $(2010 ; 2015)$ public managers and politicians can not only be "friends" of other citizens or create activities that others will follow but they are responsible for messages they produce and could involve the crowd to create innovations and policy proposals. Shared service centres have to be used to achieve more efficient and effective government by using Big-Data and "economy of scale" and by bringing tasks back to central offices or small number of shared service centres. Another idea of PVM is to concentrate on strategy-making, performance government, innovation and strategic HRM (Human Resource Management) and try to prepare the public sector and to be measurable or recognisable by the private sector and citizens. PVM is post-competitive, more focused on relationships, aggregate collective preferences and multiple objectives (also satisfaction, trust and legitimacy), with multiple accountability systems. The idea of NPM concentrates on networks and collaboration, public-private partnerships, and new ways of engaging active citizens.

As it was stated by Greve (2015), new ideas in public management differ from the NPM paradigm because of a broader use of IT technology, not only as an efficiency tool but rather as a part of a digital profile using web.2.0 and the social media and for sharing and disseminating information. New public management ideas have a different view on outcomes perception which have to be long-term and connected with public value creation, especially with a broader understanding of transparency and accountability in networks. This new idea of public management also pays attention to broader societal challenges with citizens as co-producers, co-innovators, and co-creators. This will 
create legitimacy by transparency and digital access to information and solving complex public policy problems/challenges where public managers are obliged to create public value and share experiences, risk, and results via management networks.

\section{Public institution perspectives on efficiency}

Perceiving and measuring the efficiency of the organisation is problematic and complicated especially when it is embedded in a different context, changing time, changing needs and values of the executives (Bratnicki, 2009, p. 81). This is not only because of the changes in the public management paradigm but also the nature of the measurement approaches. The most popular is the financial approach showing different facets of the value (profitability, return on investments, market value added, market capitalization, EVA - Economic Value Added). Such an approach has limitations related to predictability and the lack of participation of non-material indicators, which does not give full information on how to create wealth, especially the potential for the future (Bratnicki, 2009, p. 83). Measuring efficiency allows organisations to determine the degree of success in achieving its objectives and representation of the extent to which the objective have been achieved (Bratnicki, 2009, p. 85).

Kafel and Ziębicki (2009, pp. 240-242) broaden the perception of efficiency by using financial and non-financial dimensions such as: (1) economically-technical, (2) target-oriented, (3) institutional, (4) behavioural, and (5) systemic. The economic and technical aspects use financial evaluation of the results of the activity and the use of resources. Typically, this is cost analysis, profitability, and productivity. Target oriented efficiency considers how an organisation achieves their goals in terms of implemented services, especially their complementarity, quality, and professionalism. The institutional aspect of efficiency uses the legitimisation process and such factors as continuity of organisational activity, level of trust to an organisation and its bargaining position on the market to be legitimated in the social environment. The behavioural aspect is people oriented and considers forming interpersonal relationships within an organisation and could be measured by factors such as: fluctuation, absenteeism, working conditions, level of employees integration, interpersonal conflicts, and the scope of employees' decision-making autonomy. The systemic aspect of efficiency uses the 
level of dependency and relationships in a sector or group of companies when the effect is measured by quantity of ideas, expenditure on R\&D, value of the investment, and degree of process automation. The above interpretations may be helpful to measure HR efficiency (Hoffmann, 2014) where several methods are used to measure HR efficiency e.g. benchmarking where organisations compare HRM with others that are dealing with such kind of issues: number of employees, absenteeism index, productivity, training costs, number of training days per trainer, costs of recruitment per employee, time of recruitment, costs of health service per employee, procedures, rules, and guidelines implemented by the HRM department.

The National Development Strategy (Strategia Rozwoju Kraju 2020,2012 ) emphasises that public institutions are considered to be efficient but they have to use interpretation that is close to the citizens and its needs i.e.: (a) availability of services, open to their needs and supporting their participation, (b) quickly and effectively responding to social needs, (c) flexible, striving for benefits for all parties, (d) changing administration in management, i.e. seeking the best solutions to achieve the objectives, (e) applying a process approach and risk management, (f) open to inspection results rather than procedures and increase the participation of non-state actors in performing tasks, (g) focusing on the stabilisation of personnel and improvement of their competences, knowledge, skills, among others, through the proper motivation, (h) strengthening the role of leaders and leadership and ethics, (and) enhancing communication and circulation of information, (j) enabling the participation of citizens in shaping law and policy, $(\mathrm{k})$ preserving transparency measures and anti-corruption mechanisms.

This is similar to the interpretation of the Supreme Audit Office (NIK) in the paper on the audit of public institutions "INTOSAI GOV". It is interesting that NIK does not use the concept of efficiency, which is also true of the accompanying dictionary (NIK, pp. 56-74). It indicates that the general objectives of a public entity should be i.e.: orderly and ethical - well organised and methodical, based on the existing moral principles with the rules of fairness, impartiality, and legality. In addition, a public institution's activity should be economical, efficient, and effective, i.e. free from prodigality and extravagance, maintain an appropriate relationship between the achieved results and the used resources, and ensure a certain degree of achievement of the objectives or activity's expected effects (NIK, pp. 12-13). 
The interpretations outlined above show that searching for efficiency in a public institution applies to both financial and non-financial measures seen more as a set of general objectives, but requiring context in which they arise. The issues of the time horizon (the achieved results and the prospects for the future), or cultural influences are also important. Institutional constraints to measure efficiency give managers great freedom of the applied solutions but it seems that the optimal solution is to focus on the measures included within National Development Strategy, NIK and the guidelines given under the new ideas of managing a public institution i.e. DEG, PVM, and CG. It may be a structure for the indicators developed by the institutions alone or in cooperation with other partners.

\section{The challenges and practices of using IT in HRM}

People are the most complex resource to manage and considering the pressure on organisations for increased efficiency there has to be something more than just a mechanistic managerial approach. Bondarouk, Ruël \& van der Heijden (2009b) suggest that organisations have increased introduction of the electronic human resource (e-HRM) which is recognised as an integration of information technology (IT) applications with HRM to create value within and across organisations for targeted employees and management.

Varma and Gopal (2011) stated that e-HRM is web-based solutions that deliver an online real-time HRM solution which is different than HRIS (Human Resource Information Systems). HRIS refers to ICT systems used within HR departments (Ruël et al., 2004). HRIS is dedicated to the HR department whereas e-HRM target group is not only the HR but existing and potential employees and management.

According to Strohmeier (2007) e-HRM is the planning, implementation and application of information technology for both networking and supporting at least two individual or collective actors in their shared performing of $\mathrm{HR}$ activities. E-HRM is not the same as V-HRM or Virtual HRM which is defined by Lepak and Snell (1998, p. 216) as "a network-based structure built on partnerships and typically mediated by information technologies to help the organisation acquire, develop, and deploy intellectual capital." According to Pilbeam and Corbridge (2002, p. 98) data collected on computerised HR information systems and decisions about people use cannot be taken without consultation 
and individual agreement. The managerial view on the ability and potential of human resources needs to consider the expectations, ambitions, and opinions of the employee.

Regardless of the solution (information systems vs. e-solutions)* development of HRIS and e-HRM must be carefully assessed to maximise cost effectiveness of the data collection storage and processing relative to information needs for the different levels of managerial decision making. Pilbeam and Corbridge (2002, pp. 90-91) stated that there are three sources of HR information: individual employee data (personal details, contractual arrangements, education, etc.), HR policies and other documents (recruitment and selection, flexible working, equal opportunities, absence, etc.), and organisational data (structure, departmental details, job details, pay and reward structure, patterns of work, and others).

There are some advantages using HRIS and e-HRM solutions. Ketlley and Reilly (2003) emphasise that technology has recently developed in a way that enables e-HRM to make its mark, introduction of corporate intranets and web-enabled HRIS. They stated that development of e-HRM systems is growing, allowing the HR function to become more strategic than administrative assistance which is more visible by changing role of HR professionals. Dessler (2004) advocates that technological applications improve HR by introducing self-service, call centres, productivity improvements, and outsourcing. According to Forster (2004) e-HR combines two important elements: (1) use of electronic media, (2) active participation of employees in the process. These elements help organisations lower administration costs, improve employee satisfaction and communication, provide real time access to information and reduce processing time. Pilbeam and Corbridge (2002, p. 95) recognised that HRIS has several advantages over manual systems for example: speed of data handling and producing worthwhile information, reliability and accuracy opposite to human potential for error, storage and retrieval with less physical space and time consumption, consolidating information from different sources giving a complete picture of an individual employee in one record, decision making even with strategic implications about the direction

* Pilbeam and Corbridge do not distinguish HRIS and e-HRM but they use the term "e-revolution" to advocate that HRIS is changing into being more strategic and open for other employees. 
of the organisation's needs and developing an HR plan to reflect the corporate strategy, the role and influence of the personnel function by inclusion and participation of an $\mathrm{HR}$ specialist in the strategic planning process to became a business partner. Ruël et al. (2004) conclude that the goals of e-HRM are mainly to improve HR administrative efficiency to achieve cost reduction, standardise/harmonize HR policies and processes and reduce the administrative burden. They stated that e-HRM had hardly helped to improve employee competences.

In their research Varma and Gopal (2011) describe a lot of important challenges of the e-HRM solutions such as: fit between costs and organisational requirements and types, meet the business requirements of the company, ensure the security of information, managing the data, bewaring of the overkill of the human touch, importance to speed up on the e-HR tools for traditional companies, customisation to local circumstances, user training, ensure ROI on e-HRM project, importance of the systems integration (ERP, CRM, etc.), monitoring and feedback of any e-HRM solutions. The users of HRIS include: line managers, trainers, payroll staff, occupational health professionals, personnel specialists, and IT support (Pilbeam \& Corbridge, 2002, p. 94). E-HRM is also suitable for employees. The main advantages of the transfer of HRIS ownership to line managers are: cost effectiveness, a catalyst for change, it frees the personnel function from an administration burden (Pilbeam \& Corbridge, 2002 p. 98). Varma and Gopal (2011) suggest some considerations for enhancing the effectiveness of e-HR systems: creating an effective e-Statement, standardising and centralising HR administration in an in-house service centre, assessing and ensuring the flexibility of the e-HR technology, e-recruitment, e-retirement, and developing data-mining tools. They stated that e-HRM enables better management of an enterprise's boosting thinking, idea-generating, customer-serving human resources, it eliminates redundant activities, provides better personnel information, automates the time-consuming, error-prone HR paper trail, and there is more time to focus on strategic tasks. This is because e-HRM takes three different forms (Ruël et al., 2004) i.e. operational HRM (basic HR activities in the administrative area - payroll and personnel data administration), relational HRM (HR tools - such as recruiting and the selection of new personnel, training, performance management and appraisal, and rewards), and transformational HRM (activities with a strategic character organisational change processes, strategic re-orientation, strategic 
competence management, and strategic knowledge management). Other researchers (Sabir at al., 2015) into a cross-sectional study have indentified the contribution of HRIS adoption impact on three HRM levels: operational, functional, and transformational (strategic).

A literature review indicates that the authors give contradictory results, particularly in terms of impact of e-HRM strategic HR. According to Parry (2011) an examination of the large-scale survey results suggests that organisations are implementing e-HRM for a wider range of uses and activities when there are larger organisations, the HR function plays a more strategic role, HR specialists and HR manager have more experience, and HRM is more sophisticated. Parry (2011) stated that e-HRM may help HR to increase its value by becoming more strategic and to redeploy HR practitioners from transactional work to more strategic. The opposite view is presented in Bondarouk and Ruël's (2013) research, where there are is evidence to support the thesis that use of e-HRM enables more strategic HRM. According to Bondarouk and Ruël (2013, p. 408) the results from the single case study show that "e-HRM doesn't automatically result in direct strategic benefits and doesn't strengthen the HR function's dynamic and operational capabilities."

\section{METHODOLOGY AND RESEARCH FINDINGS}

\section{Research approach}

The research data was collected over a period of two months (March 2015 and March 2017) through the single case study approach (Yin, 2003, p. 5). According to Palermo et al. (2010) the research starts with semi-structured interviews through main actors from the management board and the HR department. This type of interview and selection of respondents stimulate the process of emerging new topics and questions because both researcher and respondents were contextually based on insights what they interpreted as relevant and important within the organization.

The study uses the exploratory case study methodology that investigates distinct phenomena characterised by a lack of detailed preliminary research, especially formulated hypotheses. Mills et al. (2010) stated that exploratory case studies are often applied in a research context 
that is not clearly specified and still requires data for the formulation of valid hypotheses. Therefore, this form of case study is very often applied as a preliminary step and provides the researcher with a high degree of flexibility and independence with regard to the research design as well as data collection.

The case study organisation, which can be called MOZ (Municipal Office in Zabrze - Silesia Province in southern Poland), was selected in the previous desk-research analysis in order to explore and present interesting issues. The desk-research was supplemented by interviews with experts from the analysed organisation, conducted through IDI (Individual in Depth Interview - the researcher uses a fixed schema thematic threads that make up the specific scenario interview). The selected institution has a good reputation and awards as an effective and innovative organisation that has implemented many interesting IT projects. This case selection is not intended to many any statistical generalisations, but to explore and to start some theoretical generalisation. The Municipal Office in Zabrze has several years of experience in e-HRM and HRIS (developed by Assecco Poland) and provides some good practices for other institutions in Poland.

The analysed unit is responsible for managing the affairs of residents and urban units within the municipality of Zabrze (Poland). According to triangulation requirements the researcher has used face-to-face interviews, observation, and analysis of documentation used for HR processes and IT solutions. The interviews were conducted in March 2015 and 2017 with decision makers within the MOZ, i.e. the HR Manager (HR Man) and the Municipal Secretary (CEO) responsible for managing the entire unit.

\section{Research findings}

Zabrze is a city in western Upper Silesia, Poland. The population was estimated to be 175,479 citizens ( $31^{\text {st }}$ Dec 2016 - www.bip.um.zabrze.pl). Zabrze is a city with a changing nature towards a post-industrial one, where the increasingly important role is played by post-industrial tourism, sport and cultural events, and education with a strong emphasis on infrastructure development (especially information technology) and research centres, particularly medical ones. The MOZ is a large-sized institution employing 651 permanent staff (mostly full-time) and 21 as replacement staff. The structure of employment shows that the 
majority of employees are women (74.5\%), where the average age of the employees is 42 and the average seniority is 11 years. The MOZ regularly trains its employees. Absenteeism due to an illness is at a low level of $3.4 \%$ but due to the employment structure there is a high level of absenteeism due to maternity leave (8.6\%). Most employees (70\%) have a degree in higher education. The MOZ also employs disabled workers, whose number amounts to $6.22 \%$ of the staff.

\section{HRIS and e-HRM solutions}

The MOZ has introduced a lot of IT solutions. The main HRIS solutions inside the City Management Support System are: employee assessment, planning career paths, electronic creation and approval of working time schedules, electronic creation and approval of working time schedules, an electronic circulation holiday card, providing a wide database of training, electronic flow of business trips, information about the assigned fixed assets and equipment, issued authorisations, information about the date of periodic tests, pictures of the staff (Weber, 2012). The MOZ also introduced solutions common to other management processes but important and integrated with HRIS and e-HRM i.e. The KSOD (an electronic document circulation system) and other smaller solutions which complement the whole system e.g. applications for city councillors, local geodetic systems, or a map of local activity etc. Besides HRIS they introduce e-HRM solutions in the area of recruiting and career search tools for candidates, recruiters, and managers. There are also in-house and governmental e-learning solutions (e.g. an e-learning platform developed by the Ministry of Administration and Digitisation of Poland).

During the study the following documents were analysed: HR annual reports, records of HRIS and e-HR presentations and in-house prepared electronic forms e.g. employee performance review and employee development review. The analysed documents were selected because of their association with IT tools supporting the process of obtaining data and their proper processing. The research started by exploring the perceived involvement in HR activities, benefits of HRIS and e-HRM solutions, and changes in employee effectiveness (Bondarouk \& Ruël, 2013).

The analysis of the interviews revealed that HR professionals did perceive themselves as having a strong involvement in any of the HR activities. Although the HR manager and CEO during the interview 
pointed out that, due to the organisational changes within the $\mathrm{MOZ}$, the HR professionals may take on more strategic roles and become perceived as Business Partners (BP). This is because HR professionals have participated in all four functions specified by Ulrich (2001, p. 51) i.e. Strategic Partner, Employee Advocate, Change Agent, and Functional Partner.

$H R$ strategy results from the organisation's strategy. HR acts as a business partner for the remaining departments to support them, especially in team building and analysing how to select the right people, counting what they do, how they do and how it affects efficiency. (HR Man)

On the other hand the HR Manager and the CEO considered transferring some organisational development activities to line managers and they were tasked with different HR practices. These support the meaning of HRIS and e-HRM in organisations to devolve HR responsibilities for individual data administration to the employees.

Departments have persons responsible for conducting the working time in every department and a department head implements the rest of the job. The system has a built-in solution, to prevent the crossing of the time during the replenishment schedules for the employees. Data from the system move to the HR department where each quarter there are monitoring reports regarding the attendance lists, absenteeism, private leave, and overtime. (HR Man)

The interview findings did not confirm that the implementation of HRIS and e-HRM solutions was accompanied by clearly defined HR roles at the MOZ, although the HR specialists expressed the view that they had less administrative and more strategic work.

Due to the implemented IT solutions our HR department can focus on analysing data and soft HR issues, not administration and data capture. Other departments and units faster access the required information. In summary it is possible to shift from personnel administration to HRM. (CEO and HR Man)

An annual analysis of personnel policies - employment, training policy, expenditure under the salary fund is conducted. (HR Man)

HR professionals saw it as becoming more strategic, more people oriented and organisational development which could be the effect of 
the implemented system. The HR manager and the CEO described it in the following way:

Local governments applied for registration of HR systems engagements, timesheets, and absenteeism. Now, as part of the development of e-government it is necessary to efficiently and quickly analyse the needs of the employees. Computerisation of these processes is essential for our further successful development. (HR Man)

In developing the HR policy for the Municipal Office in Zabrze we made the following assumptions: what is important for us is the skills, we offer opportunities for growth and job challenging, we expect a commitment to work for the benefit of the local residents. (CEO)

\section{Benefits of IT solutions in HRM}

The main benefits include a new vision of managing people in the MOZ as a public institution. The CEO stated that the changes in HRM are the result of the overall changes in IT. She stated that:

The MOZ is moving from administration to human resource management. Such systems should be aimed at attracting, developing, and retaining competent staff. (CEO)

The changes in the HRM also apply to employee evaluation by introducing efficiency criteria i.e. the quality and degree of completion of work, timeliness, compliance procedures, and execution of commands. There is also the level of qualification, especially the behavioural one. Employee assessment is also used to indicate leaders and emerging leaders. So far, employee assessment is carried out using the forms built in MS Excel. (HR Man)

The HR manager emphasised that the KSOD (electronic document circulation system) very important for HRM because of time savings within departments and IT people, more time to analyze data and work with inside clients, faster and larger scale analysis, shortened time in the decision making process, i.e. the decision-making process shortened from hours to minutes. She said that:

KSOD makes HR disseminate information about training, meetings, and assessment of workers faster. It is enough that the manager gives his/her approval and it is distributed e.g. a vacation request form automatically enters the HR system. Formerly it was a paper-intensive and time consuming process. (HR Man) 
In KSOD everyone has a virtual desk, where he or she has a document for approval or just to be able to read it which allows to create templates of documents, scanning documents, and sending them to other departments. In every department there is a person responsible for the KSOD and being the first support line for other employees, which speeds up the work and troubleshooting. (HR Man)

HR professionals perceived that time spent on different administrative activities had rapidly shortened and the time savings are the result of delegating a part of the HR tasks to the departments and trainees.

Since the introduction of HRIS and e-HRM, the time we spend on $H R$ has been divided into administration activities such as checking, recording, and organising personnel data and on strategic ones such as matching job vacancies with the organisational need or preparing reports and statistics to better develop long-term HR policies. (HR Man)

Calls to the human resources department and the information hassle are now replaced by the HRM system. The HR department can focus on analysing the data and soft issues and not on the basic administration. (HR Man)

The recruitment and selection process is the best example, because most preparations are performed by a candidate in front of his or her computer. We see the candidate only at the interview.

Using our solution an e-HRM candidate opens an account and fills in the sheet by him-or herself. As an employer, we have a quick check of his or her skills, using a template accelerates the analysis of the candidates, we are able to profile the candidates and the built-in filters allow to automate the selection process. (HR Man)

The HRM Manager summarised it using an example of the e-recruiting application:

After introducing e-HRMour institution has been working differently than before. We analyse data and discuss the possible consequences when using different HR solutions, for example our e-recruiting application. Since 2010 the candidates processed ca. 14,500 times different job offers. E-recruitment covers $90 \%$ of the managers and clerical applications. We have 5,250 registered candidates, 54 applications for each job offer on average. (HR Man) 


\section{New ideas of public management and its benefits and changes}

All the interviewees acknowledged changes in the vision of the modern public institution and HRM effectiveness. The HRM Manager stated that:

Municipalities must constantly analyse the efficiency of public services. Local governments that are aware of the challenges have to monitor the effectiveness of HRM, fundraising, raising efficiency in customer service, customer satisfaction, complete delivery on time and finding better ways to do the things we do every day. We have to look for innovative ideas from our staff and adopt them quickly. (HR Man)

The MOZ introduced the ISO9001:2000 quality management system and process management that contributed to the emergence of the following benefits:

We improved communication (data entry speed and accuracy), secured the implementation of labour law standards, enhanced data analysis, and facilitated personnel management and working hours. This is because IT solutions support better decision-making, employees review, job performance and needs, better adherence to deadlines and proper performance of the managers and departments. (CEO)

Following new requirements and working needs the CEO stated that the MOZ has to implement other efficiency improvement applications, for example project management application and software for teleconferencing and providing webinars.

As part of the process approach we constantly stimulate employees to be innovative and to be leaders in projects. That is why we need to implement solutions for project management and remote communication. (CEO)

The MOZ plans to implement systemic solutions for broader city units to centralise different aspects of management.

During 17 years of work we have created over 70 IT applications, successively building step by step in accordance with the e-Zabrze strategy ... Now we also have requested for funding a comprehensive HR system for all city units to unify different (soft and hard) aspects of the HRM i.e. remuneration, recruitment, competencies management, etc. (CEO)

They do not use too many indicators to measure effectiveness per se but they are more interested in the context of the phenomenon. 
Our main goal is to continually improve the quality of customer service... (CEO)

In the past we had ISO measurements, but we but we backed out from them because we did not get anything new. ... we have a system of management control linked to the City' strategy and the implementation of strategic goals taking into account personal risk ... We also compare our management practices with other municipalities using benchmarking within the Silesian Union of Municipalities and Districts. (CEO)

Our goals to achieve are: continuous improvement of knowledge, raising the competences of employees and managers, improving the quality of training and recruitment. We have data from annual employee evaluations, post-training surveys, job applications $(4,500$ at the end of 2016). We gathered the data from the system which has been used for: career pathways, cumulative management knowledge, personnel analysis for management, job evaluation, and human resources optimisation. (CEO)

\section{CONCLUSIONS AND LIMITATIONS}

The purpose of this article has been to identify how IT solutions influence HRM effectiveness through effective HRIS and e-HRM solutions. The findings have led to explore the key benefits of applied solutions. The interviews and observations have provided data on the different organisational levels (Table 1) i.e. strategic, tactical, and operational.

According to Pilbeam and Corbridge (2002, pp. 92-93) the strategic HRM level considers human resourcing, trends for policy review, and profiling for service planning. The tactical level uses an analysis of trends, indications of where the organisation is going and how it is doing, summary reports, aggregations, exception reports with highlighted unusual events and deviations from the standard. The operational level uses information for day-to-day management of the department. In adapting HRIS and e-HRM solutions the analysed organisation aims to maximise capabilities on three HRM levels but recommended levels seem to intersect or just have not quite clear frontiers. 
Table 1. IT influence on HRM - different levels of analysis

\begin{tabular}{|c|c|c|c|}
\hline & Strategic & Tactical & Operational \\
\hline $\begin{array}{l}\text { Nature } \\
\text { of } H R\end{array}$ & $\begin{array}{l}\text { One centralised HR } \\
\text { team supported by } \\
\text { managing board and } \\
\text { the CEO. HR team } \\
\text { responsible for HR } \\
\text { strategy, planning, } \\
\text { policies, and developing } \\
\text { knowledge and compe- } \\
\text { tencies of employees }\end{array}$ & $\begin{array}{l}\text { HR structure support- } \\
\text { ed by a service centre } \\
\text { and transactional } \\
\text { services offered by HR } \\
\text { department working as } \\
\text { a Business Partner to } \\
\text { other departments }\end{array}$ & $\begin{array}{l}\text { Delivering proactive } \\
\text { day-to-day services } \\
\text { and IT solutions to } \\
\text { departments' managers } \\
\text { responsible for opera- } \\
\text { tional HR }\end{array}$ \\
\hline $\begin{array}{l}\text { HR } \\
\text { technology }\end{array}$ & $\begin{array}{l}\text { KSOD (electronic doc- } \\
\text { ument flow). Analysing } \\
\text { and reporting all key } \\
\text { HR indicators }\end{array}$ & $\begin{array}{l}\text { IT solutions that raise } \\
\text { employee and manager } \\
\text { self-HR services }\end{array}$ & $\begin{array}{l}\text { e-HR solutions i.e. } \\
\text { e-recruitment tools, } \\
\text { electronic staff records } \\
\text { containing payroll, } \\
\text { recruitment, learning, } \\
\text { absence management, } \\
\text { competence analysis } \\
\text { tool, etc. }\end{array}$ \\
\hline Goals & $\begin{array}{l}\text { Openness - solutions } \\
\text { shared with all urban } \\
\text { units and citizens by } \\
\text { providing solutions } \\
\text { that give more oppor- } \\
\text { tunity to faster solve } \\
\text { the problems and pro- } \\
\text { vide useful information } \\
\text { to participants inside } \\
\text { the system }\end{array}$ & $\begin{array}{l}\text { Flexibility - better } \\
\text { fitted solutions with } \\
\text { decision delegation to } \\
\text { employees that results } \\
\text { in higher level of self } \\
\text { regulation and partici- } \\
\text { pation in management } \\
\text { process by employees }\end{array}$ & $\begin{array}{l}\text { Cost savings and } \\
\text { automation - less time } \\
\text { spent on operations, } \\
\text { meetings and, reporting } \\
\text { headcount (admin etc.) } \\
\text { reduction (stop raising } \\
\text { employment) - less } \\
\text { people can do } \\
\text { a bigger job }\end{array}$ \\
\hline Outcomes & $\begin{array}{l}\text { Increased speed of the } \\
\text { circuit and the trans- } \\
\text { parency of information } \\
\text { in the HRM processes. } \\
\text { Lower barriers for in- } \\
\text { formation distribution } \\
\text { and better manage- } \\
\text { ment of information. } \\
\text { Faster changes and } \\
\text { exchange between enti- } \\
\text { ties inside the network } \\
\text { of relations }\end{array}$ & $\begin{array}{l}\text { Increased self-reliance } \\
\text { and sense of responsi- } \\
\text { bility among employees } \\
\text { and their managers. } \\
\text { Higher level of self- } \\
\text { efficacy. } \\
\text { Flexible working } \\
\text { schemes and collabora- } \\
\text { tion (project manage- } \\
\text { ment and team work) }\end{array}$ & $\begin{array}{l}\text { Administration pro- } \\
\text { cesses from the HR } \\
\text { team making the tasks } \\
\text { quicker and easier; } \\
\text { workload } \\
\text { (calls) of shared } \\
\text { service centre initially } \\
\text { increased time for } \\
\text { the HR specialist to } \\
\text { monitor processes, } \\
\text { more time to do more } \\
\text { value-added work, } \\
\text { customer focus on } \\
\text { employees }\end{array}$ \\
\hline Role of HR & $\begin{array}{l}\text { Development of the } \\
\text { business vision and } \\
\text { mission. } \\
\text { Going beyond manag- } \\
\text { ing people to managing } \\
\text { talents }\end{array}$ & $\begin{array}{l}\text { Business partner } \\
\text { role development and } \\
\text { enhancement }\end{array}$ & $\begin{array}{l}\text { Inside trainers and } \\
\text { consultants for manag- } \\
\text { ers and employees }\end{array}$ \\
\hline $\begin{array}{l}\text { Role of IT } \\
\text { suppliers }\end{array}$ & $\begin{array}{l}\text { HR analysis and } \\
\text { developing right IT } \\
\text { solutions more like } \\
\text { business advisors than } \\
\text { programmers }\end{array}$ & $\begin{array}{l}\text { Developing HR tools } \\
\text { and solutions }\end{array}$ & $\begin{array}{l}\text { Implementation of HR } \\
\text { solutions }\end{array}$ \\
\hline
\end{tabular}

Source: own elaboration. 
In connection with the collection and processing of large amounts of data the MOZ CEO identifies the need for Business Process Intelligence (BPI) solutions and training. As indicated by Gołuchowski (2005, p. 140) BPI can help in a valuable analysis of the collected data, as part of a data warehouse. The Knowledge Base can help in gathering materials necessary for subsequent creation of content (including rules, laws, documents, etc.).

According to the above-mentioned benefits and debate on IT solutions in HRM (HRIS and e-HRM) does HRIS and e-HRM create strategic value? In the single case study there is evidence that value creation occurs in three ways:

- IT as a change in technology stimulates changes in HRM (direct and indirect) for a more transparent and dynamic relationships with existing and potential employees,

- IT supports the improvements in HRM by two-way transfer of best practices between the software vendors and other entities,

- IT allows to delegate routinised HR activities to line managers and employees and therefore transform HRM from an administrative to a more strategic approach.

The observed tendency to imitate appeared also in terms of corporate cultural patterns particularly in HRM and project management. However, referring to Zieliński (2011), it may be the consequences of new trends in public management that pursue efficiency analysing where the desire to imitate or use of commercial "prostheses" in public units lead to contradictory results. We agree with Zieliński that there is a transfer of "commercial" patterns which have to be fitted to the institutional context. There are also other challenges in the surveyed institution i.e.: increasing the amount of changes, increasing costs and technical requirements to new IT technologies, outdated ICT hardware, and a lack of "soft" e-HRM solutions.

Despite the challenges the findings of the single case study of the public institution revealed that adopting IT solutions (HRIS and e-HRM) aims at maximising the value creation and strategic capabilities of the HR function through changes in the HR roles, focus on HR development and knowledge sharing, performance measurement, and less administrative work. It could be important considering the mental frames important when exploring the HR role in implementing HRM innovation (Bondarouk et al., 2009a, p. 473). 


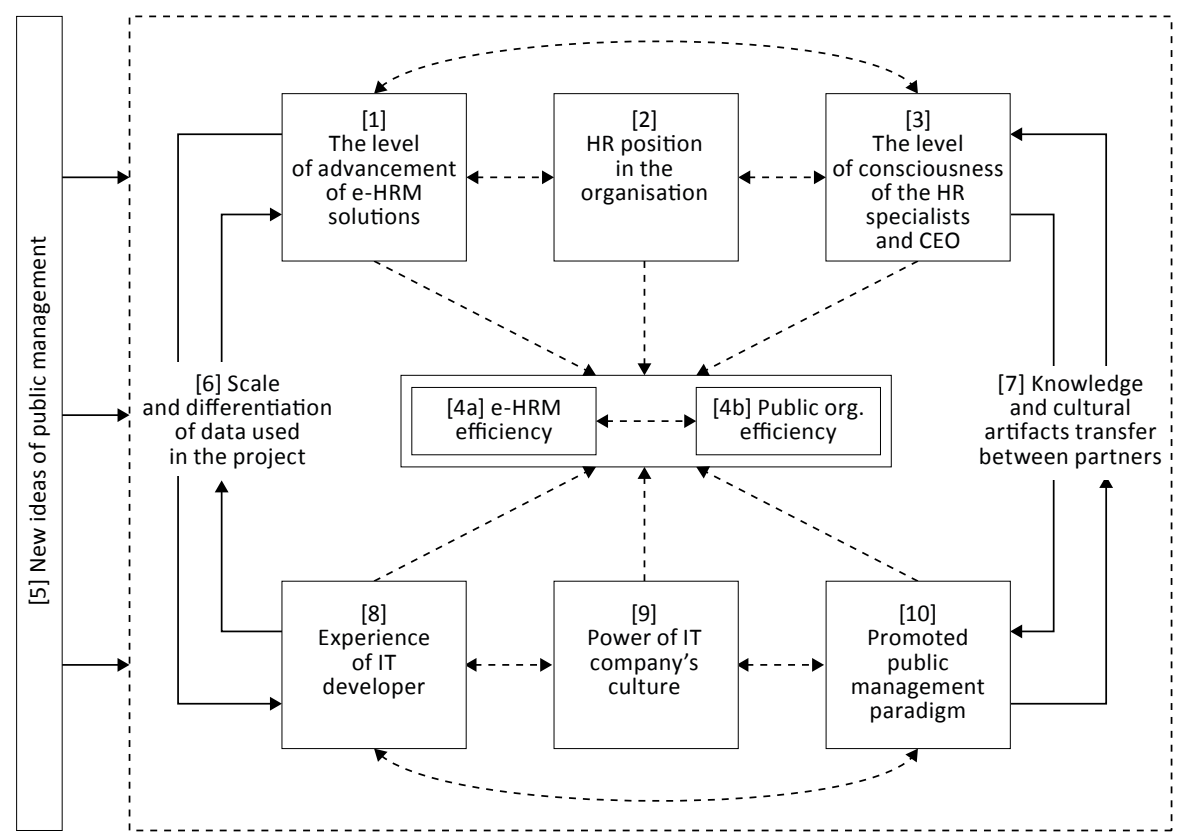

Figure 1. Model of variables useful to analyse influence of IT solutions on HR activity and efficiency of the public organisation

Source: own elaboration.

The analysis of the presented case study and other studies conducted by the author (Pyszka \& Hoffmann-Burdzińska, 2017) allow proposing a model (Figure 1) that is more relevant to better understand the role of IT in HRM and the impact of e-HRM solutions on efficiency in the public organisation.

The presented model (Figure 1) brings together the concept of HRM and the potential impact of the suppliers on efficiency, of both e-HRM solutions and public organisation that have been changed. It also considers the influence of IT suppliers as an important stakeholder with a strong impact on public organisations. Crucially for public organisations and management practices, it captures the opportunities for the development of the solutions in an economic, cultural, and integrative sense.

The future research into different e-HRM contexts will help embed the present work in a broader understanding of how and where IT solutions can be applied in public management to bring higher value. The presented model (Figure 1) is limited because of the scale of the 
study and in the sense that it encapsulates the use of a broad definition of public management and integrates it with selected HRM approaches and IT solutions. It might disregard that public organisations have different goals and IT expectations what could be significant in understanding the role of HR and IT and causes difficulties in understanding of the overall context.

\section{REFERENCES}

Bondarouk, T. \& Ruël, H. (2013). The strategic value of e-HRM: Results from an exploratory study in governmental organization. The International Journal of Human Resource Management, 24(2), 391-414.

Bondarouk, T., Looise, J.K., \& Lempsink, B. (2009a). Framing the implementation of HRM innovation: HR professionals' vs line managers in a construction company. Personnel Review, 38(5), 472-491.

Bondarouk, T., Ruël, H., \& van der Heijden, B. (2009b). E-HRM effectiveness in a public sector organization: A multi-stakeholder perspective. International Journal of Human Resource Management, 20(3), 578-590. DOI:10.1080/09585190802707359

Bratnicki, M. (2009). Pomiar efektywności organizacji świadczącej usługi publiczne. In: A. Frąckiewicz-Wronka (ed.), Zarzqdzanie publiczne - elementy teorii i praktyki. Praca zbiorowa (pp. 81-105). Katowice: Wydawnictwo Akademii Ekonomicznej im. Karola Adamieckiego.

Dessler, G. (2004). Human Resource Management. Frenchs Forest, NSW: Pearson Education Australia.

Dunleavy, P. \& Margetts, H. (2010). The second wave of digital era governance. In: American Political Science Association Conference, 4 September, Washington DC, USA [unpublished conference paper], http://eprints.lse.ac.uk/27684/ (accessed: 20 $0^{\text {th }}$ March 2015).

Dunleavy, P., Margetts, H., Bastow, S., \& Tinkler, J. (2006). New public management is dead - long live digital-era governance. Journal of Public Administration Research and Theory, 16(3), 467-494.

Forster, S. (2004). Getting greater return from e-HR investment. IRS Employment Review, 812.

Frąckiewicz-Wronka, A. (2009). Poszukiwanie istoty zarządzania publicznego. In: Frąckiewicz-Wronka A. (ed.), Zarzadzanie publiczne - elementy teorii i praktyki. Praca zbiorowa (s. 19-48). Katowice: Wydawnictwo Akademii Ekonomicznej im. Karola Adamieckiego. 
Gołuchowski, J. (2005). Technologie informatyczne w zarzadzaniu wiedza w organizacji. Katowice: Wydawnictwo Akademii Ekonomicznej im. Karola Adamieckiego. Greve, C. (2010). Whatever happened to new public management?, http://openarchive.cbs.dk/bitstream/handle/10398/8548/Carsten_Greve_KonfPap_2010. pdf?sequence=1 (accessed: $22^{\text {nd }}$ April 2016).

Greve, C. (2015). Ideas in public management reform for the 2010s: Digitalization, value creation and involvement. Public Organizational Review, 15, 49-65.

Hoffmann, K. (2014). Measuring HRM effectiveness as a challenge to contemporary HRM ccientists (IHRM context). Edukacja Ekonomistów i Menedżerów, 3(33), 7-24.

Kafel, T. \& Ziębicki, B. (2009). Wymiary i kryteria oceny efektywności organizacji pozarządowych. In: A. Nalepka \& A. Ujwary-Gil (eds.), Organizacje komercyjne i niekomercyjne wobec wzmożonej konkurencji oraz wzrastajacych wymagań konsumentów. Nowy Sącz: Wyższa Szkoła Biznesu.

Kettley, P. \& Reilly, P. (2003). e-HR: An Introduction, IES Report 398, The Institute for Employment Studies, https://www.employment-studies.co.uk/system/ files/resources/files/398.pdf (accessed: 22 ${ }^{\text {nd }}$ April 2016).

Lepak, D.P. \& Snell, S.A. (1998). Virtual HR: Strategic human resource management in $21^{\text {st }}$ century. Human Resource Management Review, 8(3), 215-234.

Mills, A.J., Durepos, G., \& Wiebe, E. (2010). Encyclopedia of Case Study Research, vol. 1-2. Thousand Oaks: Sage Publications http://srmo.sagepub.com/view/ encyc-of-case-study-research/n139.xml

NIK [Supreme Audit Office], Wytyczne w sprawie standardów kontroli wewnętrznej w sektorze publicznym INTOSAI GOV 9100, https://www.nik.gov.pl/plik/ id,5139.pdf (accessed: 20 $0^{\text {th }}$ March 2015).

OECD (2005). Modernising Government. Paris: OECD.

Palermo, O.A., Cohen, L., Loan-Clarke, J., \& Mellahi, K. (2010). Implications of new public management and modernization on control: The case of an English regional probation service. International Journal of Public Sector Management, 23(6), 535-548.

Parry, E. (2011). An examination of e-HRM as a means to increase the value of the HR function. The International Journal of Human Resource Management, 22(5), 1146-1162.

Pilbeam, S. \& Corbridge, M. (2002). People Resourcing: HRM in Practice. Harlow: Prentice Hall.

Podgórniak-Krzykacz, A. (2016). Local governance - czyli jak równoważyć zarządzanie miastem. In: Z. Przygodzki (ed.), EkoMiasto\#Zarzqdzanie. Zrównoważony, inteligentny i partycypacyjny rozwój miasta (pp. 21-43). Łódź: Wydawnictwo Uniwersytetu Łódzkiego. 
Pyszka, A. \& Hoffmann-Burdzińska, K. (2017). Wyzwania w obszarze zarządzania zasobami ludzkimi w kontekście rozwoju technologii informatycznej - wyniki badań. In: Jędralska K. \& Dyduch W. (eds.) Nauki o zarzqdzaniu. Dokonania, trendy, wyzwania (pp. 284-303). Katowice: Wydawnictwo Uniwersytetu Ekonomicznego.

Ruël, H., Bondarouk, T., \& Looise, J.K. (2004). E-HRM: Innovation or irritation. An explorative empirical study in five large companies on Web-based HRM. Management Revue, 15(3), special issue: Organisational Innovation and HRM, 364-380.

Sabir, F., Abrar, M., Bashir, M., Baig, S.A., \& Kamran, R. (2015). E-HRM impact towards company's value creation: Evidence from banking sector of Pakistan. International Journal of Information, Business and Management, 7(2), 123-143.

Strategia Rozwoju Kraju 2020 [The National Development Strategy 2020], https:// www.mir.gov.pl/rozwoj_regionalny/Polityka_rozwoju/SRK_2020/Documents/ Strategia_Rozwoju_Kraju_2020.pdf (accessed: 20 ${ }^{\text {th }}$ March 2015).

Strohmeier, S. (2007). Research in e-HRM: Review and implications. Human Resource Management Review, 17(1), 19-37.

Ulrich, D. (2001). Liderzy zarzadzania zasobami ludzkimi. Nowe wyzwania, nowe role. Kraków: Oficyna Ekonomiczna.

Varma, S. \& Gopal, R. (2011). The implications of implementing electronic-human resource management (e-HRM) systems in companies. Journal of Information Systems and Communication, 2(1), 10-29.

Weber, E. (2012). Nowoczesne podejście do zarządzania zasobami ludzkimi w samorządzie. Zeszyty Naukowe Politechniki Ślaskiej. Organizacja i Zarzqdzanie, 63a, 291-300.

Yin, R.K. (2003). Applications of Case Study Research, $2^{\text {nd }}$ edition, Applied Social Research Methods Series, vol. 34. Thousand Oaks: Sage Publications.

Zieliński, W. (2011). Efektywność ZZL w sektorze publicznym. Zarzqdzanie Zasobami Ludzkimi, 3/4, 25-34.

www.bip.um.zabrze.pl (accessed: $31^{\text {st }}$ Dec 2016). 


\title{
WPŁYW INNOWACYJNYCH ROZWIAZZAŃ IT W ZZL NA EFEKTYWNOŚĆ W INSTYTUCJI PUBLICZNEJ - STUDIUM PRZYPADKU JEDNOSTKI SAMORZĄDU TERYTORIALNEGO
}

\begin{abstract}
Abstrakt
Tło badań. Zarządzanie instytucją publiczną jest zadaniem kompleksowym przynoszącym znaczące rezultaty zarówno wewnątrz, jak i na zewnątrz danej organizacji. Badania w tym zakresie wskazują nowe wyzwania, szczególnie na styku zarządzania zasobami ludzkimi (ZZL) i wykorzystania technologii informatycznej IT, zwłaszcza że obecnie instytucje publiczne upodabniają się do korporacji, poszukując sposobów na podwyższenie poziomu efektywności działania.

Cel badań. Celem artykułu jest identyfikacja sposobu, w jaki rozwiąania IT przez efektywne aplikacje e-ZZL wpływają na ZZL oraz analiza roli tych rozwiązań w zmienianiu ZZL w instytucjach publicznych. Wskazane rezultaty tego wpływu zostały poddane analizie między innymi z perspektywy teorii nowego zarządzania publicznego i różnych pespektyw zagadnienia efektywności.
\end{abstract}

Metodologia. W artykule dokonano przeglądu literatury przedmiotu w zakresie zarządzania publicznego i wykorzystania IT w ZZL, którego celem była identyfikacja sposobów podnoszenia efektywności działania na styku wskazanych obszarów. Rezultaty przeglądu literatury wzbogacono o studium przypadku efektywnej jednostki samorządowej i zinterpretowano w świetle wskazówek z literatury przedmiotu. Przeprowadzona analiza przypadku miała charakter eksploratywny.

Kluczowe wnioski. Wykorzystanie IT w ZZL wprowadza więcej przejrzystości i dynamiki do relacji w ramach ZZL, wspiera usprawnienia w tym obszarze przez transfer najlepszych praktyk od dostawców oprogramowania i pozwala delegować rutynowe działania ZZL na menedżerów liniowych i pozostałych pracowników. Zastosowanie technologii prowadzi do zmian w procesach zarządzania talentami w organizacji. Okazuje się również, że personel odpowiedzialny za ZZL reinterpretuje swoją rolę, przenoszac uwagę $\mathrm{z}$ administrowania na strategiczne ZZL i służenie jako partner biznesowy. W wyniku przeprowadzonego badania skonstruowano roboczy model pozwalający lepiej zrozumieć, w jaki sposób doprowadzić do wzrostu efektywności rozwiązań ZZL i wyników organizacji publicznej wykorzystującej rozwiązania IT.

Słowa kluczowe: e-ZZL, zarządzanie publiczne, efektywność, model, studium przypadku. 